\title{
Auditorium Anatomicum and Theatrum Anatomicum in Gdansk
}

\author{
A. Szarszewski, M. Bogotko-Szarszewska \\ Department of History and Philosophy of Medical Science, Medical University of Gdansk, Poland
}

[Received 4 February 2014; Accepted 24 February 2014]

The widespread interest in anatomy in the $16^{\text {th }}$-century Europe echoed in Gdansk (Poland), where in 1552 anatomy was postulated as one of the subjects at the Protestant Academic Gymnasium. This demand was satisfied in 1568, 10 years after the opening of the school. Auditorium anatomicum, one of the early institutions of its kind in Europe, became a research centre before 1616 and its founding was closely connected with the activity of Joachim Oelhaf (1570-1630). The first (supposedly) public dissection of a man's head took place in 1605. In 1613 Oelhaf conducted an autopsy on a child with multiple congenital defects, which was probably the first public dissection in Central Europe. Auditorium's further development is attributed to Laurentius Eichstadt (1596-1660). Besides regular classes on anatomy, he performed three public autopsies at the auditorium (1651 and 1655), similarly to Georg Seger (1629-1678), Johannes Glosemeyer (1664-1711) and Johann Adam Kulmus (1689-1745). The dissections were solemn ceremonies attended by the municipal authorities. Auditorium functioned until 1741, when it was allocated for other purposes. Consequently, Gdansk was deprived of a permanent dissection room. Theatrum anatomicum was temporarily arranged in the Wide Gate but soon closed for financial reasons. An attempt to locate it in the Green Gate also failed. In 1778 autopsies were performed in the Bell-Founder's Gate. The gate, however, was demolished in 1803, and when Ephraim Philipp Blech (1757-1812), the last professor of anatomy, died no one was appointed to the vacancy. Eventually, the Gymnasium closed in 1817. (Folia Morphol 2014; 73, 3: 239-246)

Key words: anatomical theatre, anatomy teaching, Gdansk Academic Gimnasium, renaissance and early modern medicine

The rapid development of human anatomy in the $16^{\text {th }}$ century led to widespread interest in this branch of science among the educated social strata. Study of the human body, which for thousands of years had to conform to legal and moral norms, became at that time a part of the cultural landscape of early-modern Europe. Sixteenth century thus, marks the date when the educational model regarded examination of the physicality as a necessary element of self-knowledge. However, due to the controversy surrounding anatomical practice, autopsies had to take place beyond the reach of unauthorised eyes. On the other hand, they were to be performed in such a way that those interested in this unusual spectacle could experience it as fully as possible. In the late $16^{\text {th }}$ century this conflict was resolved through formation of the so-called anatomical theatres, which would satisfy both demands. 
Thus anatomical theatre became a specific shrine of knowledge, where only the selected ones were invited to a spectacle. Quasi-theatrical performances, with corpses as the main attraction, gained in popularity. Pompous and directed in keeping with the Baroque taste for splendour and ostentation, the spectacles created an opportunity for a given community to prove its maturity by cultivating science despite the repulsive stench of death. The taste for ugliness and macabre, so characteristic of the period, went hand in hand with the genuine interest in the research problem. As a result, science practiced to the accompaniment of music (played by the town council bands) and created against a background of eloquent speeches was tamed and could be consumed by an ever growing audience.

So far, the anatomical research centres of early-modern Gdansk (Poland) have not been discussed in a separate scientific report. Some information on the subject can be found in the works of Eduard Schumann [25], Edward Loth [15], Stanisław Sokół [27], or in the recently published joint publication edited by Edmund Kotarski, Lech Mokrzecki, Zbigniew Nowak, Zofia Głombowska and Mariusz Brodnicki [14]. And yet this is an issue of particular interest, especially when observed against the background of other developing centres. Gdansk was one of the first towns in Central and Eastern Europe to become a centre for promoting a new approach to the study of human body. The city's new status as a medical scientific hub gave rise to Gdansk Academic Gymnasium, an important educational centre, whose rise the city owes to the Reformation. The first signs of the emergence of new religious ideas in Gdansk come from the year 1518 , and the most turbulent were the events in 1525. Although the religious and social revolt which took over the city was suppressed by the Polish king, Sigismund I the Old, its aftermath was a gradual conversion of a growing number of citizens to Lutheranism or Calvinism. Eventually, King Sigismund II August of Poland, accepted the city's new religious identity and in 1557 granted the townsmen freedom of religion. The King's decree found its ritual expression in a distribution of Holy Communion under both kinds, whereas politically it resulted in secularisation of most of the religious convents.

One of these convents was a Franciscan monastery. Situated in a part of Gdansk called the Old Suburb (Vorstadt), it was taken over by the town council as early as in 1555 . There, the council intended to establish a school whose level would be somewhere between secondary school and university and which would be designed for Protestant youth. The school (as studium particulare) opened on $13^{\text {th }}$ June 1558.

As early as 1552 one of its spiritual founders, physician and pharmacist Johannes Placotomus (1514-1577), thinking of the future Gymnasium, wrote a short work on the benefits of teaching medicine (Oratio de ratione discendi ac praecipue medicinam, Leipzig 1552). This same author in his next essay (Ein gemeiner und kurtzer Bericht von christlichen lateinischen Schulen zu bestellen, Königsperg in Preussen 1562 ) suggested that lectures on medicine should be based on the work of Luther's friend, Phillip Melanchton (1497-1560) Liber de anima.

With this growing awareness of medical sciences in the city, the teaching of medicine began in 1568, 10 years after Gymnasium was established. It was conducted by Andreas Frackenberger (1536-1590), a graduate of the University of Wittenberg, who had no medical training and was a professor of rhetoric and history. He drew his knowledge from Liber de anima. It seems, however, that the main reason for this were not so much the suggestions of Placotomus, as the fact that Frackenberger was himself Melanchton's student. His master believed that the curriculum at schools such as Gdansk Academic Gymnasium should be as broadly-based as possible. Frackenberger expounded his mentor's views in Constitutio nova Gymnasii Dantiscani (1568). In his work he postulated that studying Liber de anima 'helps to maintain health and identify diseases, and provides guidelines for resolving intricate issues' (p.54). Melanchton's original work was a compilation of new anatomical discoveries made by Andreas Vesalius (1514-1564) and old theories formulated by Galen (around 130-200 A.D.) $[9,18,27]$. The latter still weighed heavily on the views of the first teacher of medicine in Gdansk, Frackenberger, who claimed in the announcements of his anatomy classes that 'in Phisicis fabricam partium corporis humani ex Galeno'. (State Archives in Gdansk, hereinafter referred to as APG, 300,42/258, p.9v).

It seems clear that in Gdansk of that time anatomy was not taught at the dissecting table but was merely based on reading selected texts. In 1576 Frackenberger moved from Gdansk to Wittenberg and the lectures were discontinued [5]. From 1584 to 1603 the work of Frackenberger was taken up by Johann Mathesius (1544-1607). Although Mathesius was a Doctor of Medicine, he gave his lectures in the 
same way as his predecessor, basing them on Liber de anima. This was because he was a student of Melanchton in Wittenberg [20]. The first to perform public autopsies in Gdansk (and in general in this part of Europe) was Joachim Oelhaf (1570-1630), appointed in 1603 professor of anatomy and medicine. He studied in Wittenberg, but also at the University of Padua. The acquired skills allowed him to run the first autopsies in Gdansk. The oldest record of Oelhaf's practises can be found in the chronicle of Eberhard Bötticher, who at the end of 1605 wrote about a section of a man's head that (at least to some extent) was a public event (the Gdansk Library of the Polish Academy of Sciences, hereinafter referred to as BGd, Ms.Uph18, p.450). Moreover, Oelhaf performed a section on a child with liver pathology (exact time unknown) and in 1609 he carried out a post mortem examination of Bartholomeus Keckermann (1572-1609), a professor of Gdansk Academic Gymnasium (BGd, Sa35,8 No.8,

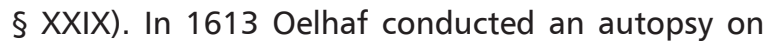
a child with multiple malformation syndrome, and he published the results [19]. It is generally believed to be the first public autopsy in this part of Europe. Despite this achievement, however, the daily teaching of anatomy still relied solely on lectures, and the only sections that Oelhaf would perform for his students were those on fish. This is probably the reason why in 1616 Marton Csombor, a Hungarian student of Gdansk Academic Gymnasium at the time, wrote with disapproval '(...) auditorium anatomicum, which I do not know whether because of indolent professors or indolent students, during my time there could not fully develop'.

Csombor's text is notable for yet another reason: for the first time it mentions the name of the venue where Oelhaf taught: auditorium anatomicum. It was 1 of 4 large rooms designated for lectures, disputations, final exams and promotions that Gymnasium had at its disposal [17]. Auditorium anatomicum was situated in the eastern wing, from the south adjacent to the library hall and from the north to the chancel of the Holy Trinity Church. It was a vaulted, 3-bay hall of considerable size. The term: auditorium confirms the above mentioned assumptions - its original purpose was to give lectures on anatomy (and medicine) and not to perform autopsies. Otherwise, it would have been called theatrum anatomicum, in accordance with the generally accepted terminology of the time. The term theatrum anatomicum can be encountered as late as $18^{\text {th }}$ century and refers to a hall outside Gymnasium (see below).
Unfortunately, the only description of the auditorium dates back to 1713 . Ephraim Praetorius notes that this hall, also known as "Honorarium", was intended for solemn occasions. The author continues: 'it is sometimes referred to as "Anatomicum", because it becomes a place for anatomical sections. Auditorium also serves as a lectern and has been fitted with seats arranged in an amphitheatric manner, from where it is very convenient to observe anatomical demonstrations' [20].

The detailed equipment of auditorium is not known. From the above description it can be concluded that like in other European buildings of this type, there was a dissecting table in the centre, encompassed with seats that would rise in tiers. Typically, dissection rooms were oval, but in the case of Gdansk the seating layout must have been adapted to the rectangular shape of the room. A similar and relatively rare arrangement of a post-mortem hall could be found in the so-called Anatomical House (Domus Anatomica) opened in Copenhagen in 1643/44 [2]. In 1758 Michael Hanow (1695-1773) mentions a sarcophagus, a lectern, and benches that would make up the room decoration until 1741. Unlike in other theatres of the period, there were probably no curiosities adorning it. It seems that initially even as obvious a prop as a human skeleton was missing. This may be inferred from a note by Samuel Schelwig (1643-1715), a librarian of Gymnasium, who in 1676 extols Christian Hanemann for donating a complete skeleton to the library (a room adjacent to auditorium). Hanemann's gesture offered first-hand knowledge of what had been so far learnt exclusively from the works of eminent anatomists (BGd, Od 17548,2).

The term auditorium anatomicum had already been well established when in 1645 Laurentius Eichstadt (1596-1660) was appointed its professor of anatomy and medicine. He graduated from universities in Greisfald, Wittenberg, and Jena, and was a distinguished anatomist and physician. He was the first in auditorium to teach anatomy based on human autopsies. The 15 years when Eichstadt worked at Gymnasium were the glory days for anatomy in Gdansk. Every Monday at two o'clock in the afternoon, he would teach his classes by presenting 'primates, humans and rules that apply to what is closest to human nature as well as definitions and causes of diseases' [17]. Eichstadt was the first professor of anatomy in Gdansk to perform autopsies for students, 
and their presence during sections was probably a necessary condition for receiving credit for his class. He conducted 3 public dissections and submitted detailed reports on them (BGd, Oe112,8, p.55, Ms 514, p.109) [5]. While performing autopsies, Eichstadt used the latest discoveries in anatomy. For example, he demonstrated the pancreatic duct discovered in 1642 by Johann Georg Wirsung (1589-1643) and he popularised the views of William Harvey (1578-1657) on blood circulation (BGd, Ms 514, p.106, 108) [21]. Eichstadt believed that it was impossible to teach the basics of medicine without the knowledge of anatomy. He advised a very critical approach to literature data. Instead, he stressed the importance of actual hands-on experience. He supported his thesis by elaborating on differences in the anatomy of animals and humans, a subject which was much discussed at the time. The scholar argued that reliance on animal anatomy, characteristic of many former anatomy books, lead to a false picture of the inside of a human body [7].

Before Eichstadt conducted the first public dissection in 1651, he had had the auditorium anatomicum refurbished as it was in quite poor condition (APG $300,42 / 120$ p.13). Then, he ordered the printing of invitations in which he wrote: 'this programme is to be read with due attention and courteous kindness by researchers and all others interested in the dissection. It is known that nearly fifty years ago the distinguished members of the Senate and magnificent rectors of our Gymnasium established here in Gdansk the Anatomical School, which has boasted such figures as a physician and former anatomist, Joachimus Oelhafius, who gained fame with public debate on viscera in 1613, as mentioned in the programme. Similarly, now the generous rectors, who are most kind judges to the cause of science and who wish well to anatomical study, give us the place and cadaver to enable our future growth in this field. The gifts we heartily welcome and hereby publicly announce' (BGd Sa59,8, No 7). Besides those invited, there were also people who paid for the opportunity to participate in the anatomical spectacle.

Before another public dissection in 1655, Eichstadt again printed a 'public notice to researchers and all those interested in the dissection and eager to know the construction of human body. The courteous kindness of the most benevolent magistrates for the old town should be widely announced and recognised, for they care about the growth and promotion of anatomical studies at our Gymnasium and endeavour to obtain a proper female corpse for the anatomical theatre. Not only naturalists would benefit from this, but also surgeons and midwives and so the magistrates' efforts might help in difficult cases of childbirth or prevention of miscarriage. (...) We are lacking neither young physicians nor experienced surgeons, and dissections, or a process of disassembling, could be performed better and more frequently. It seems to have been customary for gymnasia and academies that those who were neither high officials of the magistrate, nor lay judges, neither church clerks nor physicians, neither scholars, nor surgeons or midwives, brought in their tickets and were admitted as well' (BGd Ma 3918,8, No 133).

The dissection was carried out in auditorio anatomico on $16^{\text {th }}$ April 1655 (APG 300,42/258, p.17; BGd Ms 504, p.37). The next public autopsy was held in auditorio anatomico in March 1676 and was conducted by Dr Georg Seger (1629-1678) (APG 300,42/258, p.26; BGd Ma3980,2).

In the first half of the $18^{\text {th }}$ century, Gdansk found a worthy successor of Eichstadt in the person of Johann Adam Kulmus (1689-1745) [10]. As a student, this eminent scholar used to take classes on anatomy at Gdansk Gymnasium, where he attended lectures of professor Johannes Glosemeyer (1664-1711). Glosemeyer, according to West European fashion of his time [3], conducted public dissections accompanied by solemn and pompous ceremonial. He followed in Eichstadt's footsteps and issued invitations a few days before a dissection. Same as before, they were partly ticketed and included a reference to the permission granted by the town council. The invitations also briefly presented the person who was to be examined. The ceremony in auditorio anatomico was preceded by speeches of the Town authorities and accompanied by music played by the municipal band. Then the case of the person undergoing a section was discussed in detail. It took over an hour before the cadaver was finally opened and the autopsy often lasted for several consecutive days. The young Kulmus must have been greatly impressed by such ceremonies. When he became a professor at the Gymnasium, Kulmus himself actively participated in them. After his graduation in Gdansk, he studied in Halle, Frankfurt (Oder), Jena, Altdorf, Strasbourg, and Basel. The last stage of his scientific peregrinations became Leiden, where he was a student of Herman Boerhaave (1668-1738). In 1725, Kulmus returned to 
Gdansk and took the Chair of Anatomy and Medicine at the Gymnasium. Kulmus's induction ceremony was celebrated with great solemnity, in accordance with the prevailing practice of the Gymnasium. The professor later recalled: 'on 23 May (1725), at the age of thirty six, I was appointed by the city of Gdansk to the position of a municipal physician and professor of medicine at the Gymnasium and succeeded the late Doctor Johann Glosemeyer, whose position had been vacant for thirteen years. A traditional ceremony of installation was held on 28 June (1725). It started with an oration "De philosophiae naturalis usu in Athenaeo" delivered by Dr Abicht, the Rector. Then I had another oration "De philosophiae naturalis cum reliquis scientiis connubio". After the introduction ceremony was over I asked professor Hoheisel (Karl Ludwig Hoheisel, 1692-1732, professor of Greek and Oriental languages at the Gymnasium) who had been installed shortly before me, whether he had given the bandmaster any money and how much (because I heard that the bandmaster is paid twenty thalers by the council and yet he demanded of me gratification)' (APG 300,42/273 p.65). Unfortunately, Hoheisel's response has not been preserved.

To his dismay, Kulmus found auditorium anatomicum devastated after it had not been used for 13 years. It had to undergo a renovation, so that in 1727 and 1736 it could once again become the scene for public dissections conducted in a manner of pompous ceremonies. In 1727 Kulmus demonstrated the construction of the cardiovascular system, according to the teachings of Harvey, whose discovery was still not well known at the time. In 1736 Kulmus performed a public dissection of a camp-follower, who had run a rather dissolute life. She ended up in the gutter begging and getting drunk, and finally hanged herself [15].

Auditorium anatomicum was not the only place in the Gymnasium where classes on anatomy and medicine were held. For example, Joachim Oelhaf gave all his disputations known to us today elsewhere. In auditorio magno (acroaterio maiore) took place the following disputations: De foetu humano (10 March 1607), De manibus (12 May 1607), De cruribus (7 July 1607), De dentibus (8 December 1607), De Cerebro (21 March 1609), De corde (10 July 1610), De abdominis (9 February 1613), De ventriculo (15 May 1613). Disputations: De Peste (6 April 1626) and Problema physiologicum an ventriculi (May 1630) were held in auditorio philosophico (acroaterio philosophico).
Undoubtedly, all these disputations were held when auditorium anatomicum had already existed (BGd, Sa34,8; Sa35,8).

Laurentius Eichstadt gave some of his classes on anatomy and medicine in auditorio anatomico (acroaterio anatomico): De generatione \& corruptione, seu ortu corporum naturalium (6 September 1657) and De generatione imperfecta, quae fit praeter intentionem generantis, adeoq. de monstris (7 November 1658), some of them in auditorio philosophico: De vitris (1654), and some in auditorio maximo: De peste (6 December 1657). On the other hand, in auditorio anatomico Eichstadt held his disputations: De tempore (July 1659) and De vacuo (3 April 1659), which were quite distant from medicine. Similarly, Johann Glosemeyer would give regular lectures in auditorio anatomico on meteorites (1708-1710), but at the same time he conducted there public dissections (the already mentioned Demonstationes anatomicas cadaveris masculini, 26 November 1696; BGd, XIXq,291, Ma 3981,2, Sa34,8; Sa 35,8).

Auditorium anatomicum also hosted teachers of other subjects. Thus, for example, in auditorio anatomico (honorario) Frideric Büthner had a disputation De cometarum (1666), in 1684 Samuel Schelguigus held Pronunciata philisophica, in 1687 Johannes Gabriel Schlieff - Ex philosophia morali de iure naturae, in 1689 Johannes Christoph Rosteuscher - De lustitia Armorum. In 1702 there were series of lectures given by Christian Sahm: De motu telluria, De situ telluria, De figura Terre and Gottlieb Schelguigius: De Dubois Juramentorum Formulis, Ex Principiis Juris Naturae (BGd, Sa 34,8, Sa 35,8).

Johann Adam Kulmus carried out his anatomical studies at the Gymnasium until 1741. On June $3^{\text {rd }}$ (that year) the town council decided to allocate auditorium anatomicum to the teaching of the school's fourth and fifth forms (APG 300,42/273, p.77r.). Apart from the need for a convenient place to conduct such classes, the immediate cause for a such change lay in the complaints of the stench that accompanied the sections, and which was too irritating for the nose of Samuel Willenberg (1663-1748), a professor of law and the school inspector rolled into one. As a result, theatrum anatomicum was moved to the Wide Gate (Breiter Tor; BGd, Od 17548,2).

Unfortunately, Kulmus's successor, Christian Sendel (1719-1789), is not regarded today as an eminent anatomist and physician. There has been no information about autopsies which he would perform as 
part of anatomy teaching. During his term of office in 1752, auditorium anatomicum was finally closed. In 1756 the venue was allotted to the expanding library of the Gymnasium (BGd Ms 504, p.261). Nevertheless, even after the liquidation of auditorium anatomicum, anatomy classes based on lectures and disputations were continued. Some classes were private lessons, which the lecturers were forced to give due to low salaries they received. In 1765 private tuition lessons provoked a heated dispute with the school authorities, who looked unfavourably on such practices. Eventually, private classes were maintained and were given to future physicians as well as surgeons and midwives (APG 300,42/156, p.144). The town council - admitting in 1766 the right of professors to private lessons - expressed hope that this privilege would not be abused by them (APG 300,42/273, p.95v).

The closure of auditorium anatomicum in 1741 was a disastrous move. The new anatomical research centre, located in a different part of the town than the Gymnasium (in the Wide Gate), turned out to be a great disappointment. Soon, due to lack of funds, the classes at the centre were suspended. Under the circumstances, Benjamin Schwarz, the town physician, suggested in 1752 setting up theatrum anatomicum in the Green Gate (Grüne Thor). At that time, the Gate was occupied by the Nature Society in Gdansk (Naturforschende Gesellschaft in Danzig) with whom Doctor Schwarz made a deal. According to the agreement, Schwartz was to equip theatrum at his own expense, but after his death all the accessories would be taken over by the Society. Unfortunately, the project did not come to fruition because the scholar did not manage to raise the necessary 3000 guilders [25].

The main clientele of the classes held in auditorio anatomico and in theatro anatomico were, in addition to future doctors, journeymen of the barber-surgeons' guild in Gdansk. For their time, the barbers' anatomical education was of a very high standard. Moreover, the masters of the guild also benefited from the cadavers when they practiced on them for more difficult surgeries. Therefore, the problems with the dissection room mainly affected the barbers of the town. At the time when in Gdansk there was no venue for autopsies, the guild addressed the municipal authorities with a petition (1755) to establish theatrum anatomicum for the specific needs of the surgeons. In the petition they called anatomy 'der Seele und das Fundament der Chirurgie' (the soul and foundation of surgery), the view which was uncommon among European barber-surgeons of the time (APG 300,10/314, p.267-268).

Midwives of Gdansk were yet another separate group of those benefiting from anatomy teaching. They were given that educational opportunity by Laurentius Eichstadt as early as 1655 (BGd, Ma 3918,8, No 133, p.4). Based on autopsies of women who died in childbirth, the municipal authorities issued a regulation in the second half of the $18^{\text {th }}$ ordering the training of midwives [13]. The surgeons' supplication from 1755 also raised this question but due to the closure of the theatre, the midwives could not properly educate themselves either. As a result, the barber-surgeons' guild engaged in a cooperation with the Oliva Gate Lazaretto and used its corpses of the deceased patients. The petition the guild submitted to the municipal authorities in 1755 to allocate them a place for anatomy classes, even a closed bath house, remained unnoticed. The tense political situation in Europe in the late $18^{\text {th }}$ century put Gdansk in a disastrous economic position, and the Gymnasium, unreformed and poorly funded, drifted toward destruction. When in 1778 anatomical classes were resumed, they were held in the vicinity of the Wide Gate - the Bell-Founder's Gate (Glockentor) and they were delivered not by professor Sendel, but by Dr Matthias.

The last professor who attained the Chair of Medicine and Anatomy was Ephraim Philipp Blech (1757-1812). He did not leave behind any significant anatomical treatises. Professor Blech, entrusted with the position of the town physician and a physician at the Lazaretto, performed dissections in that very hospital [1]. Also some exams in surgery took place there (APG 300,C/75, p.25). Under Blech's chairmanship theatrum anatomicum in the Bell-Founder's Gate ceased to function for some time. Unfortunately, the exact date of this fact remains unknown, but it must have happened before 1793 because we know that after theatrum anatomicum was closed, professor Blech would give lectures on human anatomy to the journeymen from the barber-surgeons' guild of Gdansk. The lectures were held in a house assigned by the Mayor of Gdansk, Eduard Friedrich von Conradi (1713-1799) [25], and, as the records suggest, Conradi was in office between 1761 and 1793. There is, however, no information whether dissections were also performed there. The anatomical theatre reopened in the Bell-Founder's Gate before 1799, yet the 
Gate was soon demolished (1803) [28]. After Blech died in 1812, there were no further appointments to the professorial vacancy at the Gymnasium and the school closed in 1817.

Auditorium anatomicum and theatrum anatomicum were not the only places in Gdansk where dissections were conducted. In some cases autopsies for teaching purposes were performed at a physician's house (e.g. 1679, Dr Ludwig von Hammen, section in a private home; BGd, Ma 3981,2, No 91). Moreover, at least from 1454, barber-surgeons of Gdansk were obliged to perform post-mortem examinations of the deceased who had died a violent death. In 1589 the town council ordered the barbers and the town physician to perform obductions on such deceased persons. Initially, the examinations were limited to a visual inspection without the body being dissected [22]. However, already in the late $17^{\text {th }}$ century, town physicians and masters of the surgeons' guild in Gdansk carried out full forensic autopsies of the presumed victims of violence, as was already common practice in some other areas of Europe. Between 1691 and 1769 there were at least 200 such examinations. In due time, new methods specific to forensic medicine emerged. The first test to detect the presence of air in the lungs of the deceased was done in Gdansk in 1716 (the procedure was introduced into the European judiciary in 1681). The role of the surgeon during a forensic autopsy was to perform the examination and then report the results to the municipal physician. In such cases the dissections took place in the New Bench House, and sometimes even at the houses of the deceased. At least since the mid-18 ${ }^{\text {th }}$ century, the autopsies were also performed in the Oliva Gate Lazaretto, which functioned as a municipal hospital. The post-mortem examinations were restricted to the patients of the hospital and were performed by the hospital physicians $[23,26]$.

Thanks to both auditorium anatomicum and theatrum anatomicum Gdansk became an important spot on a scientific map of the early-modern Central Europe. The theoretical basis for anatomical theatres was formed by Alexander Benedictus of Padua as early as in 1497. Carolus Stephanus unfolded visions of such buildings in his treatise De dissectione partium corporis (Paris 1546), but his ideas were turned into practical application as late as 1594 in Padua. The auditorium in Gdansk, initially used only for lecturing and later also for performing dissections, was established between 1568 (the first lectures in anatomy) and 1616 (the first mention of auditorium). Given the fact that the first anatomical theatre in Europe was created in Padua in 1594, it seems unlikely that an independent room designated for teaching anatomy existed in Gdansk before that date. At the same time, it seems that lectures in anatomy did not require a special auditorium. Thus, the venue meant as a separate room for teaching anatomy should be associated with Joachim Oelhaf (from 1603). He is known to have dissected fish, which so little satisfied Marton Csombor. Therefore, auditorium was most probably established between 1603 and 1616. Unquestionably, it became the place of performing public autopsies in 1645, when Laurentius Eichstadt was appointed the chair. Until then, several anatomical theatres had been established in Europe (apart from Padua), namely in Leiden (1597), Amsterdam (1619), Bologna (1637), London (Theatre in the Barber Surgeons' Hall, 1638), Copenhagen (1643/44). Only later theatres in Altdorf (1650), Groningen (1655), Uppsala (1662), Kiel (1666), London (London College of Physicians, 1674), Frankfurt Oder (1689) and Paris (1694) were to be built [24]. For years, many esteemed research centres did not have adequate places to perform dissections, even for their students. At a time when Gdansk could already boast a working auditorium anatomicum, Joseph Mede, a student at Cambridge University complained in the academic year 1627/28 that: 'it took place twice a day the last two days. I was once there, but saw it so ill accommodated that I came no more; for it was in the regent house upon a table, when only half a score doctors could come to see anything, standing close by the table, and so hindering others seeing, which was the chief; for I can read as good as they could hear, and with more ease. It will be next time I hope better, for our new doctor will have one every year' [4].

In fact, University of Cambridge received the halls to perform public autopsies in 1716 , which was later than Berlin (1713). Other anatomical theatres were founded even later, for example in 1725 in Würzburg, in 1731 in Ferrara, around 1745 in Prague and around 1750 in Vienna.

The nomenclature poses a separate problem. As a rule, in Europe the buildings were called anatomical theatres. Occasionally, however, one can meet auditoria anatomica e.g. in Gdansk but also at universities in Prague [16], Oxford [12], Ingolstadt [11], Uppsala [6], or Åbo Akademi in Turku [8]. In the case of Gdansk, the name was justified by the history of the room 
itself. On the one hand, the term auditorium described the actual destination of the hall which originally served only to give lectures; on the other hand, it referred to the names of other halls at the Gymnasium, like auditorium maximum, auditorium philosophicum, auditorium ordinarium. Consequently, the common term theatrum anatomicum was attributed in the $18^{\text {th }}$ century to a venue situated outside the Gymnasium. The sources clearly indicate that at least from the mid- $17^{\text {th }}$ century until 1741 auditorium served as an anatomical theatre, a function to which it had clearly been adapted using a typical amphitheatric design.

As it has been mentioned before, the moving of a dissection room outside the building of the Gymnasium in 1741 proved to be an unwise decision. Since then, continuously moved from place to place and intermittently closed and reopened, the theatre no longer fulfilled its function. In the late $18^{\text {th }}$ century it became the source of serious problems for the guild of barber-surgeons, which faced liquidation. When the Prussian authorities decided to move master craftsman's exams to Berlin, one of the arguments for the move was the fact that Gdansk did not have an anatomical theatre (APG, 300,C/75, p.134). The barber-surgeons argued that a public anatomical theatre (ein offentliches Theatrum anatomicum) did exist in Gdansk, in the so-called Bell-Founder's Gate (auf dem sogenanten Glockenthor), and that renown professors of the local Gymnasium taught there (sic!) (APG, 300,C/75, p.136). All in vain. The decision of the authorities in Berlin remained unchanged. The anatomical theatre in Gdansk became a useless relic.

Lectures on anatomy were resumed as late as 1940, when the existing Staatliche Akademie für Praktische Medizin zu Danzig (the State Academy of Practical Medicine in Gdansk), established in 1935, was transformed into a full profile medical school - Medizinische Akademie Danzig. Professor Rudolf Spanner (1895-1960), who a year earlier was nominated for the Noble Prize, became the Head of the school. But this is a completely separate chapter in the history of science in Gdansk.

\section{REFERENCES}

1. Adreßbuch der Königl(ichen) West-Preußischen See- und Handelstadt Danzig und der combinirten Städte Stolzenberg fürs Jahr 1796, Danzig.

2. Bartholin Th (1662) Cista medica Hafniensis variis consiliis, curationibus, casibus rarioribus, vitis medicorum Hafniensium, aliisq; ad rem medicam, anatomicam, botanicam \& chymicam spectantibus referta. Accedit ejusdem Domus anatomica brevissimè descripta. Typis Matthiae Godicchenii, Hafnie.
3. Brockbank W (1968) Old anatomical theatres and what took place therein. Med Hist, 12: 371-384.

4. Cunningham A (1993) The Anatomist Anatomis'd: An Experimental Discipline in Enlightenment Europe. Ashgate, Farnham.

5. Czerniakowska E (1992) Franckenberger Andrzej. In: Gierszewski S ed. Słownik Biograficzny Pomorza Nadwiślańskiego. Vol. 1. Wydawnictwo Gdańskie, Gdańsk, pp. 431-432.

6. de la Motraye A (1918) Resor 1711-1725. P.A. Norstedt \& Söners Förlag, Stockholm.

7. Eichstadt L (1655) Programma invitatorum ad dissectionem publicam, typis Rheti, Gedani.

8. Hartman GI (1804) Specimen philosophicum de differentia notionum instrumentalium \& realium. Vol. I. Typis Frenckellianis, Aboae.

9. Helm J (1996) Die Galenrezeption in Philipp Melanchthons De anima (1540/1552). Medizinhistorisches J, 31: 298-321.

10. Heß W (1883) Kulmus, Johann Adam. In: Allgemeine Deutsche Biographie. Bd 17, Duncker \& Humblot, Leipzig, p. 364.

11. Heym S (1984) Henrico Zuccalli (um 1642-1724), der kurbayerische Hofbaumeister. Schnell \& Steiner, München.

12. Hyde T (1760) Veterum Persarum et Parthorum et Medorum religionis historia. E Typographeo Clarendoniano, Oxonii.

13. Köstlin R (1904) Die Entbindungs-Lehranstalt von Westpreußen bis zum Jahre 1825, ein Bericht von Dr. Franz Christian Brunatti. Sonder-Abdruck aus den Schriften der Naturforschenden Gesellschaft in Danzig, Bd. XI, H.1/2, Naturforschenden Gesellschaft in Danzig, Danzig.

14. Kotarski E, Mokrzecki L, Nowak Z, Głombowska Z, Brodnicki M eds. (2008-2012), Gdańskie Gimnazjum Akademickie. Vol. I-V. Wydawnictwo Uniwersytetu Gdańskiego, Gdańsk.

15. Loth E (1928) Gdańska Szkoła Anatomiczna. Archiwum Historji i Filozofji Medycyny Oraz Historji Nauk Przyrodniczych, 8: 1-20, 208-228.

16. Mayer von Mayersbach JI (1725) Collegia anatomico-practica. Typis Georgii Labaun, Pragae.

17. Mokrzecki L (2008) Gdańskie Gimnazjum Akademickie: zarys dziejów. In: Kotarski E ed. Gdańskie Gimnazjum Akademickie. Szkice z dziejów. Wydawnictwo Uniwersytetu Gdańskiego, Gdańsk.

18. Nutton V (1993) Wittenberg anatomy. In: Cunningham A, Grell OP eds. Medicine and the Reformation. Routledge, London, New York, pp. 11-32.

19. Oelhaf J (1613) Foetus monstrosus in pago Prust territorii Dantiscani editus Anno Domini MDCXIII die 27 Februarii Bene fide delineatus et descriptus. Typis Hünefeldi, Dantisci.

20. Praetorius E (1713) Athenae Gedanenses, sive commentarius historico-chronologicus succinctus, originem \& constitutionem Gymnasii Dantiscani illustris. J.F. Gleditsch \& Filium, Lipsiae.

21. Pszczółkowska ZL (1992) Eichstadt Wawrzyniec. In: Gierszewski S ed. Słownik Biograficzny Pomorza Nadwiślańskiego. Vol. 1. Wydawnictwo Gdańskie, Gdańsk, pp. 384-386.

22. Raszeja S (1997) Z dziejów medycyny sądowej w Gdańsku. Archiwum Medycyny Sądowej i Kryminologii, 47: 111-113.

23. Schmidt O (1943) Sektionsberichte aus Danziger Physikatsakten der Jahre 1691-1769, ein Beitrag zur Geschichte der gerichtlichen Medizin. Int J Legal Med, 37: 203-217.

24. Schumacher GH (2007) Theatrum Anatomicum in history and today. Int J Morphol, 25: 15-32.

25. Schumann JHE (1893) Geschichte der Naturforschenden Gesellschaft in Danzig. Commissions Verlag von Wilhelm Engelmann in Leipzig, Danzig.

26. Sokół S (1957) Historia gdańskiego cechu chirurgów, 1454-1820. Ossolineum, Wrocław, Warszawa.

27. Sokół S (1960) Medycyna w Gdańsku w dobie Odrodzenia. Zakład Narodowy im. Ossolińskich, Wydawnictwo Polskiej Akademii Nauk, Wrocław, Warszawa.

28. Stephan W (1954) Danzig: Gründung und Strassennamen. Johann Gottfried Herder-Institut, Marburg. 